\title{
Trade Secrets in Indonesia: How Can We Protect Them?
}

\author{
Andry Setiawan ${ }^{1 \mathrm{a}}$, Dewi Sulistianingsih ${ }^{1 \mathrm{~b}}$ \\ ${ }^{1}$ Department of Private and Commercial Law, Faculty of Law, Universitas Negeri Semarang (UNNES), Indonesia

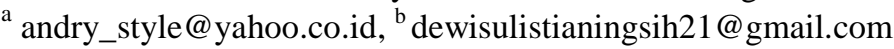

\begin{abstract}
IPR (Intellectual Property Rights) provide explicit choices for intellectual property owners to register their works or not. The logical consequence of making the registration is that the right owner can demand legal protection. However, it's quite different from a trade secret, having its own characteristics, in which the law does not declare the necessity for a registration to earn protection. A trade secret will receive protection even if it is not registered. The registration itself even will eliminate its secrecy. Measures to protect trade secrets are not easy and require special efforts. There have been many ways carried out but there are also many ways which make us lose its secret nature. Protecting confidential information is not an easy task. There must be concrete actions from the trade secret owner. The government do not only act as the regulator but they also act as the motivator seeking to provide service excellence for establishing economic stability as well as ensuring legal protection for the people. Trade secrets are influential assets to Indonesian economy. It is important that business owners to protect their assets which are economically profitable and influential to their business sustainability. Trade secrets have distinctive charateristics from that of other intellectual properties, for instance patents. Trade secrets are different from public secrecy which makes it exculsive from the information dsiclosure. The new breakthrough offered by the Ministry of Law and Human Rights of Indonesia is to require trade secret registration in Indonesia. It is needed to study further about how it is conducted and what its purpose is. This paper reveals the existence of the trade secret registrations conducted by the Ministry of Law and Human Rights of Indonesia, what is the purpose and objective of doing so, and whether it is not against the law.
\end{abstract}

Keywords-Trade Secret; Intellectual Property; Indonesia

\section{INTRODUCTION}

Ideas, concepts or information are important for everyone. The idea, concept or information they have could be of high economic value [2]. It depends on how they realize the idea or concept into something of value and make the information valuable. There are many ways to make that happen. Any action taken must be well-thought in such a way for its effects both its advantages and disadvantages. Someone could have kept something as a secret or a confidential piece of information for so long and waited for the time to reveal it to public [5]. It will be a problem when the person does not have sufficient knowledge on how to reveal the information that it results in his or her loss of economic benefits.

The information, ideas, and concepts become important for the business world if they become the main ingredients to build a business. It is understandable that many businesspeople try to keep their information, ideas, or concepts secrets, so that their businesses can run as they have expected. For businesspeople, confidential information is a crucial thing for their business sustainability.

Companies regularly seek to maintain their most valuable information in confidence. Their reason for doing so is simple: a company that can keep its valuable information secret can then use the information--and the resulting innovations--to gain an advantage over those of its competitors that lack srch insights (Epstein, 1988:887). Every business/ venture shall always have confidential information which is included in a secret category as trade secrets. Trade secrets can be said as complicated things if the owner does not understand their importance for his business or venture. It is important for businesspeople to acquire knowledge about the importance of the trade secret itself. Trade secrets are very valuable and have many advantages for their owners providing that the trade secret owner knows how to manage it well. Poor trade secret management by it owners will result in losing their competitive power or characteristics as valuable assets for them.

Broadly speaking, trade secrets are a kind of information that has value because it is not disclosed in general. A lot of valuable information may appear trivial and because it does not receive enough appreciation. In addition, many businesspeople are not aware of it. They will realize its importance when their competitors/business counterpart tries to win the market or to create marketing plans by approaching/ talking with the employees to gain knowledge about the trade secrets owned by the businesspeople they work for [16]. By then, they will have realized that they have something valuable to protect. The more business people realize that their information knowledge is valuable needed to win in a business competition, the more efforts they will make to protect their trade secrets. The technology and creativity advancement that is growing rapidly leads to the need of saving a formula, a recipe, and so on in order that they are not known by the public since the secrets have economic 
value for the holder if it remains confidential. And more importantly, this is a private right that needs a protection.

\section{RESEARCH METHOD}

The approach method used in this study is juridical normative. Juridical normative is an approach to the study of applicable legal issues in this case those regarding the trade secret with an analysis of legal protection for the trade secret owners. The specification of the research is descriptive analytical, in which the researchers describe government policy (in this case the Ministry of Law and Human Rights) in providing services to the community, especially in the legal aspect. The data were taken from the interviews and literature study results. The collected data were then analyzed using a qualitative analysis on the bases of legal theories, legal principles, doctrines, laws and legislation relating to the problem under study so that they could give answers to the problem.

\section{RESULT AND DISCUSSION}

Trade Secrets are also known as Undisclosed Information (WTO/TRIPs) or Confidential Information (England), or Trade Secret (US), and in Indonesia it is called Rahasia Dagang (Trade Secret). Trade secrets is part of the intellectual property rights system which deserves the same protection as do other IPR objects, such as Copyright, Trademark Rights, Patents, Industrial Design Right, etc. Trade secrets are defined as information including a formula, patterns, compilation, programs, engineering methods or processes that produce economic value independently, concrete and potentially [12]. Methods in trade secrets that include confidential information are among others: (1) Production methods, which are all pieces of information that are needed to make an item, like what materials are contained and the amount, etc.; (2) Processing methods, which are all pieces of information on how to process the materials to make them ready for consumption; (3) Sales methods, which mean all pieces of information which involves strategies for marketing goods that are ready for consumption.

\section{A. The Protection of Trade Secrets: A Necessity}

The difficulty in protecting trade secrets becomes every country's concern. In principle, secrets can not only be protected by morality and religion but also by law. One of the law functions is to give protection to human interests. While in order to protect human interest, the law must be implemented and enforced. It reflects the values of justice and prosperity. It is also expected to reflect value system, both as a means that protects the values or as a means to realize the community behavior. The law becomes a logical and consistent rule if it was made effectively and it is supported by proper facilities. The law protects the owner of trade secrets from the actions of other parties that can harm the owner of a trade secret.

The trade secret, which is information considered confidential in the technology and/or business fields. The protection itself is automatically given to the information deemed confidential providing that it remains confidential, has economic value and is kept confidential through appropriate efforts. Therefore, the trade secret rights do not have a protection period. As long as the criteria of the information are maintained, the protection of the trade secrets still applies to that information. A piece of information is considered confidential if it is only known by certain parties, such as the company information that is only known by the director of the company.

A piece of information is considered to possess economic values if it can be executed for commercial activities or business or if it can increase economic profits, such as client lists, a list of suppliers of goods from a company, etc., and because it is detail, the information can provide the economic benefits for the company. Any information is considered confidential if the owner has taken proper or appropriate measures such as storing a food formula in a safe deposit box as well as making a confidentiality agreement between the company and the employees or a third party.

The mechanism of trade secret protection is fully the responsibility of the trade secret owner. He or she has to keep it secret so as not to disclose it to the public. Therefore, the period of the protection of trade secrets is as long as the trade secret is not disclosed. There is no registration for trade secrets. Trade secrets shall not be registered. Trade secrets are only stored by the owner of the trade secret solely. This intellectual property rights is special because it does not need to be registered and does not need to be announced to get legal protection. In this, the secret information has to be maintained and provides a competitive advantage to its owner, may qualify for trade secret protection. A trade secret protection is unlike a patent and copyright protection because it must be kept secret. In this trade secret owner must not apply in the government for protection. In this owner simply establish and maintain trade secrets as internal matters [4].

The right over the trade secret includes the right to use the trade secret itself and the right to license to or prohibit other parties from using or disclosing such trade secret to the third parties for commercial purposes. The protection of trade secrets in intellectual property rights is indeed unique. This is due to the characteristics of trade secrets that are very different from other intellectual property rights such as brands, patents, industrial designs, integrated circuit layout designs. The confidential information used in trade can be said as an idea or a concept that comes from human intellectuals that also need to be protected because of justice issues and appreciation for the owner of trade secrets. Not every confidential information in trade will always get protection from the intellectual property. It is also not easy to categorize that information in the trade to be trade secrets.

Not all confidential information is a trade secret. There are several factors used to determine whether the secret can qualify as a trade secret. This factor is about the extent of the actions taken by the secret owner to maintain its confidentiality. These actions regulate all of the conveniences and difficulties for information which can be acquired by others. Based on these considerations, the 
general rule is that information can be protected as a trade secret. If the information has spread widely to the public, then the information is no longer referred to as a trade secret. If adequate security measures are taken to keep the information confidential so that the public will not know, then the information is still considered a trade secret. The owner of trade secrets may disclose the trade secrets to others providing that they promise not to disclose them to others. The owner of the trade secret must watch the promise and must anticipate if the promise is broken. The most basic question is what if someone/ a business person loses his or her trade secret information because they have disclosed it to others even though with an agreement that the people to whom the confidential information is disclosed will not disclose it to others. It is worse when the giving information on trade secrets is only based on trust.

Each party, in this case the employees of a company which owns a secret trade and also government employees that perform the examination are required by the law no to disclose any acquired information. If the information evidently happens to be disclosed by unauthorized parties, the secret trade owner can sue any party who discloses the secret trade based on the articles 13, 14 and 17 of Act No. 30 of 2000 concerning Trade Secrets.

Information can be simply inventoried whether it is categorized as a secret trade or not by analyzing the information. For example, is the information included as business information? Does the information have economic values? Is the information included in the category of product methods, business methods or marketing methods? Who holds the information, a public body or a business person? Is the public body managing the information is bound by a confidentiality agreement? Has the owner of the information ever licensed the information? Are there concrete measures that are carried out by the owner to protect the information?

If the analysis turns out to state that the information is general information, even it is owned by government agencies, the information cannot be called as a secret trade. A trade secret is different from public secrecy. Therefore, in Indonesia, a trade secret does infringe any information disclosure Act, which is the Act No. 14 of 2008 concerning Public Information Disclosure. One of the public information sources or providers is the public sector or agency, while a trade secret is owned by a business person or an individual, and not a public sector or agency. In general, the difference between a trade secret and the public secrecy lie in the freedom of information. In addition, the community has the right to information that is categorized as public. Meanwhile, a trade secret is information that is private and is a personal right which is protected by human rights.

The provisions of Article 17 letter b of Act No.14 of 2008 regulate the reasons for public information to be categorized as excluded information. Clearly, the provisions include a reason for the exclusion, which is if it is opened and given to a Public Information Applicant, it can interfere with the interests of IPR protection and protection from unfair business competition.
The enforcement of Act No.5 of 1999 is intended to create a fair competition climate. Any conspiracy to obtain company's confidential information is considered a form of anti-competitive action. It is possible that public information contains confidentiality that has been used as a competitive tool some for business people. Therefore, the provisions of Article 17 B of Act No.14 of 2008 are provisions that have necessary protection for confidential information in the viewpoint of both Intellectual Property Rights and Business Competition.

Indonesia's regulations regarding trade secrets are summarized in the Act No. 30 of 2000 concerning Trade Secrets, to enable Indonesian citizens to conduct honest and healthy competition in the national and global markets. Indonesian entrepreneurs are prepared to compete and enter the business competition, so the Indonesian government give incentives to every business person who protects his or her rights to avoid from unfair competition, which is very vulnerable to happen in trade secrets. Businesses that are prone to unfair competition are restaurants that are included in the culinary sector, in which the information that has economic value like recipes is stolen and then copied by other business people, which makes the owner of the recipe suffer from losses while the fraudulent business people gain unfair profits.

The protection of trade secrets has advantages and disadvantages. The advantages of protecting trade secrets are: (a) that it does not have registration fee (a trade secret is not registered), fees are paid only for the inclusion of a transfer or registration of a Trade Secret license agreement; (b) that the protection of trade secrets does not require disclosure of secrets (in contrast to that of patents); (c) that the protection of trade secrets is not time bound; a trade secret will always be protected as long as the secret owner continues to maintain its confidentiality; (d) that a trade secret has a direct effect on the company; recipes or formulas of a product are important assets for the company. Trade secrets are very important assets for the company because they are related to the continuity of the company. The disadvantages of protecting information as a trade secret are: (a) that other parties can perform a reverse engineering, and that is legal under Indonesian law; (b) that the trade secret law enforcement is difficult, it may lead to a situation in which the protection of the trade secret ends when there is no concrete efforts or measures to protect it.

\section{B. Trade Secrets vs. Patent}

A trade secret is the same as other intellectual property such as patents, brands, industrial designs, and is regulated in the laws and regulations of each country by referring generally to the provisions contained in the TRIPs Agreement [10]. The article 39 of the TRIPs Agreement stipulates that member countries must protect "undisclosed information" (trade secrets) against any unauthorized use by carrying out methods which are in contrast to fair business competition. Such information should not be known in general or easily accessible [14], must have value because of secrecy, and "security measures" must be taken to keep it confidential. The article 42 to 49 of the 
TRIPS Agreement covering law enforcement requires each country to have a judicial process in place to enforce all intellectual property rights and protect "confidential information" although proving violations of trade secrets will vary from one country to another.

Most business people own a secret trade in running their business. A secret trade is very valuable and useful form of intellectual property right. It is very suggested that a business person take adequate measures to protect the secret trade because it can ensure that the company gains business profit more than their competitors. In addition, it is also suggested that the business person able to prove that his or her company make efforts for keep it secret. A company has alternatives to enforce the company rights against people who abuse its secret trade.

A secret trade can become a valuable component of intellectual property, either as a patent complement or as an alternative patent. There are four types of intellectual property rights: patents, copyrights, trademarks, and trade secrets. Only two of these intellectual property rights protect information: patents and trade secrets. Patents protect information by dedicating the information to the public in return for a limited monopoly. Trade secrets protect information with independent competitive value derived from the secrecy of the information [9]. The company benefits from utilizing the intellectual property and gain unique benefits from the trade secrets and patents by protecting these types of information. The secret trade protection is automatically available without any government intervention, while patents will only be available after submitting an application and being approved by the government. But, the patent process is slow and rather costly [13].

Patents and trade secrets are the only two forms of intellectual property that protect information-patents protect patentable information (innovation), while trade secrets can protect patentable information and any other information providing economic value to the holder. Thus, the same information can often be protectable by patents or trade secrets (Mcgurk, 2015: 190).

Both secret trades and patents are parts of IPR, but they have differences. In short, trade secrets can include information that is either patentable or not and is unpublished, does not have a time limit, and is nonexclusive. Patents are limited to objects that are determined by law, are published in a definite time limit, and are exclusive [3]. Different from the patent law, a trade secret law does not create a monopoly for the trade secret owner. Conversely, the trade secret itself will only effect against any party who improperly uses the trade secret and also act against people who use improper means to acquire the information. Unlike the patent law, the trade secret law does not create a legal monopoly in favor of the trade secret owner. Instead, the trade secret owner only has a cause of action against any party who wrongfully appropriates the trade secret, as well as a cause of action against the person who utilizes any illegal or unethical methods to acquire the secret information [8]. An open or patented sale provides legal support for exclusive disclosure, but it also involves leakage of a certain portion of the knowledge to the public in the process of filing a patent application [1].

Obtaining rights over a patent requires a disclosure to obtain legal protection, a trade secret is not protected in the same way as that of other forms of intellectual property, such as patents, copyrights, trademarks, etc. However, the protection of trade secrets offers a wider scope than that of patents, trademarks, or copyrights. A patent requires that the invention to be a novelty, useful, and non-obvious, have been disclosed to the public, and is in accordance with the definition of patented subject matter. Trademarks protect only what is printed or product reference images or services in trading. Copyrights only protect the expression method but not the content (ideas), information, or concepts (being processed).

Trade secrets cover broader category than patents. Patents need novelty and have inventive steps. Trade secrets can include inventions, but they can also include information that must not be acquired by the competitors/ competitors don't want to know. Trade secrets do not require novelty requirement, so the owners of trade secrets can have the advantage from the protection of trade secrets which patents cannot provide. A customer list is an example of information that a patent cannot provide but it can be protected by trade secrets. Protection for the customer list is something that must be carried out since it is not easy to get a list of customers, the process goes through negotiations, investigations, etc. The list of customers can fulfill the requirements as information that can be protected by trade secrets if the owner of the information takes concrete measure to protect the customer list [7].

The protection of trade secrets can be carried out: (a) when the secrets are related with the production processes or inventions but not for the products, like products which is more likely to be engineered and therefore it can be protected as trade secrets; (b) when the trade secrets are not considered to be of great value and they just deserve to be granted a patent; (c) if the secret is not patented; (d) if there is a possibility to keep the information confidential for a long period of time like more than 20 years (patent protection period); (e) when a company has registered a patent and is in the process of waiting for the patent to be granted. For example, in some countries inventions must be kept as trade secrets until it is decided whether they continue to become trade secrets or obtain a patent.

The protection of trade secrets is generally weak and more difficult to be enforced. It only protects against improper acquisition or utilization or confidential information disclosure. If the secret is disclosed, anyone can have access to it. The weakness of trade secrets is the high cost connected with the implementation of safety and information protection policies, controls, supervision. Furthermore, other people may find independently or may register a patent. If trade secrets can be patented, we have to be careful before deciding whether to register it as a patent or keep it as a secret. Companies must consider what type of knowledge is involved and contemplate for its use since this protection may seem very attractive to businesspeople. 
The prohibited actions may include obtaining and using trade secrets and an unauthorized disclosure to the third parties. An disclosure of a trade secret to the public whether it is intentional or not generally will make it no longer a trade secret. It is also prohibited to intentionally or unintentionally obtain or use trade secrets obtained incorrectly. Furthermore, a disclosure of valuable commercial information that is too early, including knowledge, can be damaging or fatal for the subsequent efforts in the protection of patents or the registration of industrial designs. An invention or design shall be kept as a trade secret until it is decided whether it continues becoming a trade secret or a patent or registered as an industrial design. In this case, when a company intentionally or unintentionally reveals the trade secrets, the condition will lead to the registration of patents or industrial designs .

\section{Trade Secrets Transfer}

The article 5 (1) of Act No. 30 of 2000 concerning Trade Secrets mentions legal events which could result in the transfer of trade secret rights. The transfer of trade secrets can be carried out through inheritance, grants, wills, written agreements, or other reasons justified by the legislation. The transfer of rights on the basis of an agreement is required when making a deed, especially an authentic deed. This is important considering that the aspects covered are so broad and complicated, as well as to safeguard the interests of each party that is involved in the agreement of transfer of the trade secret rights [15].

The transfer of trade secret rights caused by "other reasons justified by the regulations" can be explained here, for example concerning the court verdict related to bankruptcy. The trade secret owner or holder can also license other parties based on a license agreement to implement or use the trade secret rights for commercial activities. The license only grants limited rights within a limited time period. It is quite different from the agreements that becomes the basis for the trade secret transfer. The license is granted for utilizing the trade secrets within a certain period. The licensing is based on the consideration that the nature of the trade secrets is closed to other parties. The implementation of the licensing is carried out by sending or utilizing experts who can maintain its secrecy.

The holder or the owner of the trade secrets, during the licensing process, can still carry it out by himself or herself or involve a third party related with licensing his or her trade secrets. In principle, the licensing agreement is nonexclusive, meaning that it still gives the owner of a trade secret the possibility to give a license to another third party. The license agreements is not supposed to contain provisions that directly or indirectly harm the Indonesian economy, or contain provisions that result in unfair business competition as regulated in the applicable laws and regulations. The laws and regulations referred to in this provision are Act No. 5 of 1999 concerning Prohibition of Monopolistic Practices and Unfair Business Competition.
The administrative or registry mechanisms, both for various forms of trade secret rights transfer and trade secret license agreements shall be registered in the Directorate General of Intellectual Property Rights (IPR). The provisions regarding this mandatory registry will not open access to the publications of the trade secrets, because what is registered is not the substance of the trade secrets but only the administrative data from the transfer of rights and license agreement documents. This requirement for registry is stated in Article 5 paragraph (3) jo Article 8 paragraph (1) of the Trade Secret Act. Announcements made regarding the trade secret rights transfer and licensing agreements in the Official Trade Secret Reports also do not include substantial matters but only the administrative data. Documents of trade secret rights transfer and licensing agreement documents that are not registered in the Directorate General of Intellectual Property Rights will result in having no legal consequence for third parties since the document in question is not registered.

The Government Regulation of the Republic of Indonesia No. 45 of 2016 concerning the Second Amendment complements to the Government Regulation No. 45 of 2014 concerning Types and Tariffs of the Applicable Types of Non-Tax State Revenues in the Ministry of Law and Human Rights. This regulation states that the registry fee of the trade secret rights transfer is $\mathrm{Rp}$. 400.000 (four hundred thousand rupiah) and the registry fee for a trade secret license agreement is Rp. 250.000 (two hundred and fifty thousand rupiah).

The data collection of trade secrets from all Indonesian citizens will only be registered if there is a license agreement from a business person or a trade secret owner. Therefore, if the information is desired to be used as a license then such information shall be registered in the Directorate General of Intellectual Property Rights. The Directorate General of Intellectual Property Rights provides services for the registration of trade secret rights transfer and also the registration of trade secret licensing agreements. The owner of a trade secret who registers is imposed with a payment of Non-Tax State Revenues. In the license registration section, the Director General of IPR only registers the license agreement, which is the licensing agreement between the third party and the trade secret holder.

Trade secrets are not registered and there is no data collection for the confidential information. They are only registered if there is a license. Moreover, the registration only includes the license agreement. The Directorate General of Intellectual Property Rights also maintains the confidentiality of the information by not collecting the data on the confidential information regarding the owners of trade secrets. There is no division that handles the trade secrets in the Ministry of Law and Human Rights in the Central Java Regional Office. There is also no special division that provides services for trade secrets and the registration of trade secret licenses, because the Regional Offices do not have the authority to record trade secret licenses. These services can only be provided by the echelon 1 level or the Directorate General of Intellectual 
Property Rights. There is a division that provides services for the trade secrets in the Directorate General of Intellectual Property Rights. The division which provides services for trade secrets at the Director General of Intellectual Property Rights is the Directorate of Copyright, Industrial Design, DTLST and Trade Secrets, in which there is also a registry section of trade secret licensing agreements. Their duties are: (a) registering the trade secret licensing agreements; (b) providing legal services to handle cases relating with trade secrets.

The concrete forms of the legal protection from the Directorate General of Intellectual Property Rights for trade secrets owned by businesspeople are: (1) in terms of administration, there is a registration of trade secret licensing agreements; (2) in terms of law, the Directorate General of Intellectual Property Rights provides services and explanations or information as an expert witness in a case of trade secrets; (3) the Directorate General of Intellectual Property Rights conducts an investigation if there is a criminal case regarding trade secrets. The Director General of Intellectual Property Rights cooperates with the Indonesian Police through Civil Servant Investigators for Intellectual Property; (4) in terms of the regulation, the Directorate General of Intellectual Property Rights is preparing provisions for the registration of trade secrets that will be submitted to the Ministry of Law and Human Rights.

\section{CONCLUSION}

The way every country protects trade secrets vary. Generally, trade secrets protect all types of secret information, either it is commercial, industrial or personal. Trade secrets are included as Intellectual Property, beside brands, patents, industrial designs and copyrights. Anyone who owns confidential concept information can be protected, because trade secrets are included into the category of Intellectual Property. Nevertheless, trade secrets are different from other intellectual property.

Trade secrets can be transferred or granted to other parties. All transfer forms of trade secret rights must be registered in the Directorate General of Intellectual Property and are imposed with a registration payment. Trade secret transfers that are not registered in the Directorate General of Intellectual Property have no legal effect on third parties. The transfer of trade secret rights is announced in the official trade secret report. Especially for the transfer of rights which is based on an agreement, there is a need for a transfer of rights which is based on the issuance of an authentic deed made by a notary. The word authentic is used in order to maintain the interests of each party and the deed can be used as evidence of proof.

\section{REFERENCES}

[1] Bhattacharya, Sudipto \& Sergei Guriev. (2006). Patents vs Trade Secrets: Knowledge Licensing and Spillover, Journal of the European Economic Association, Vol. 4, No. 6, pp 1112-1147.

[2] Beckerman-Rodau, A. (2002). Trade Secrets - The New Risks to Trade Secrets Posed by Computerization, Rutgers Computer and Technology Law Journal, Vol. 28, pp 227-273.

[3] Besen, Stanley M \& Leo J. Raskind. (1991). An Introduction to the Law and Economics of Intellectual Property, Journal of Economics Perspectives, Vol. 5, No. 1, p 3-27.

[4] Choudhary, Sarika, et al. (2013). Program and Data Protection: Copyright, Patent, Trade Secret and Trademark, Indian Journal of Computer Science and Engineering (IJCSE), Vol. 4 No.3, pp 235-239.

[5] Dreyfuss, Rochelle Cooper. (1998). Trade Secrets: How Well Should we be Allowed to Hide Them? The Economic Espionage Act of 1996, Fordham Intellectual Property, Media and Entertainment Law Journal, Vol. 1, No. 9, pp 1-44.

[6] Epstein. Michael A \& Stuart D. Levi. (1988). Protecting Trade Secret Information: A Plan for Proactive Strategy, The Business Lawyer, Vol. 43, No. 3, pp 887-914.

[7] Friedman, D. D., W. L. Landes, and R. A. Posner. (1991). Some Economics of Trade Secret Law, Journal of Economic Perspectives, Vol. 5, No. 1, pp 61-72

[8] Gutterman, Alan S. \& Robert brown. (1997). Intellectual Property Laws of East Asia, HongkongSingapore : Sweet \& Maxwell Asia

[9] Halligan, Mark. (2010). Trade Secrets v. Patents: The New Calculus, Lanslide Journal, Vol. 2, No. 6, pp 1-3.

[10] Linton, Khatherine. (2016), The Importance of Trade Secrets: New Directions in International Trade Policy Making and Empirical Research, Journal of International Commerce and Economics, pp 1-17.

[11] Mcgruk, Michael R \& Jia W. (2015). The Intersection of Patents and Trade Secrets, Hastings Science And Technology Law Journal, Vol 7, No. 2, pp 189-214.

[12] Nomani, M.Zafar M \& Falzanur Rahman. (2011). Intellection of Trade Secret and Innovation Laws in India, Journal of Intellectual Property Rights, Vol. 16, pp 341-350.

[13] Pace, Christopher Rebel J. (1995). The Case for A Federal Trade Secrets Act, Vol. 8, No. 2, hh 427-469.

[14] Risch, Michael. (2007). Why Do We Have Trade Secrets?, Marquette Intellectual Property Law Review, Vol. 11, Iss. 1, pp 1-76.

[15] Tanjung, Aminah. (2016). Implementation Of Trade Secret In Indonesia (Study Of Industrial Area Medan, IOSR Journal Of Humanities And Social Science, Vol. 21, Issue 11, pp. 24-37.

[16] Wiesner, Ryan M. (2012). A State-By-State Analysis of Inevitable Disclosure: A Need for Uniformity and a Workable Standard, Marquette Intellectual Property Law Review, Vol. 15, iss. 1, pp. 211-231. 